\title{
FORMALIZATION OF POWERS AS AN ELEMENT OF OBTAINING THE LAWYER'S LEGAL STATUS
}

\section{Zaborovskyy V. V.}

\section{INTRODUCTION}

A lawyer's empowerment is an important element in his/her professional activity since it not only establishes the essence of his/her relationship with a client but also determines the peculiarities of the lawyer's individual legal status. It is determined by the fact that, on the one hand, documents that certify the lawyer's powers, in particular, can determine the limits of his/her procedural capacity, and on the other hand - the proper registration of the lawyer's powers is undoubtedly a guarantee of his/her successful preparatory as well as all subsequent activities in providing professional legal assistance. In addition, the proper formalization of the lawyer's powers is, first of all, one of the main guarantees of a qualified professional judiciary (legal) assistance to a client (first of all, regarding the client's realization of his / her claims concerning the lawyer's unlawful activity).

The relevance of the study topic is also manifested by the fact that from the moment of attaining a lawyer's status, a person receives only a professional status, however, the realization of a significant number of elements of this status is impossible beyond his/her exercise of their procedural and (or) nonprocedural form of advocacy activity, therefore, full realization of a professional component of the lawyer's status is possible only with the proper formalization of the lawyer's powers. It is determined by the fact that from the moment of the lawyer's powers formalization and his/her introduction in the corresponding process (providing documents confirming his/her powers to certain authorized entities), he/she acquires an appropriate individual legal status, which gives him/her the opportunity to fully use the complex of professional (provided by legislation on the bar) as well as procedural rights.

Unfortunately, neither in theory nor in practice the uniform approaches have been elaborated as to the proper formalization of the lawyer's procedural powers. Despite the fact that most procedural codes clearly state the grounds and documents confirming a lawyer's powers, there are cases when courts and other authorized entities unreasonably fail to recognize the validity of their powers on the basis of certain documents. Regarding the non-procedural form of the lawyer's activity, given the multifaceted possibility of its realization, it can be argued that the law enforcement activities of other institutions and organizations do not differ from courts in these matters. 
The relevance of the study is also evident in the fact that the provision of the Law of Ukraine "On the Bar and Practice of Law» ${ }^{1}$, according to which the authority of an attorney as of the counsel for the defendant or as of the representative in commercial, civil, administrative proceedings, criminal proceedings, administrative offence proceedings, as well as of the representative authorized by the assignment in constitutional proceedings shall be verified in the order prescribed by law is prescribed by law (Part 3, Art. 26), specifies the need to analyze the provisions of the procedural codes governing these issues.

The analysis of the provisions in the current versions of the procedural codes indicates that the CPC, EPC and CAP of Ukraine have established identical norms prescribing that the lawyer's powers as a representative are confirmed by a power of attorney or a warrant. It indicates that in these types of procedures, the Ukrainian legislator no longer provides for the possibility of confirming the lawyer's powers through a contract on the provision of legal services and the assignment by a body (agency) authorized by law to provide free legal aid. In contrast to civil, administrative and economic litigation, the CPC of Ukraine and CUAO points to the possibility of using such documents to certify a lawyer's powers in court, which indicates the inconsistency of the Ukrainian legislature in determining the list of documents that can be used to certify a lawyer's powers in a particular type of court and the need to examine the legal nature of each of them.

\section{Legal aid agreement as a basis for the advocacy practice}

According to the provisions of the Law of Ukraine "On the Bar and Practice of Law", the sole basis for the practice of advocacy is a legal aid agreement. Such agreement, in the new editions of the CPC, EPC and CAP of Ukraine, was a document that could confirm the lawyer's powers in all types of proceedings.

Unfortunately, the overwhelming majority of the advocacy establishment (especially young lawyers), as D.P. Fiolevsky rightly points out, inappropriately treated the conclusion of such an agreement with the client, moreover, some of them dispensed with such a "formality" at all $^{2}$. There is also an assertion that such an agreement (contract, deal) is treated as a legal professional privilege and therefore cannot be "provided as a document confirming the lawyer's powers to participate in the case" ${ }^{3}$. We do not share this view, but agree with the position of the Ukrainian legislator, who not

1 Про адвокатуру та адвокатську діяльність: Закон України від 5 липня 2012 р. № 5076-VI. Офічіийний вісник Украӥни. 2012. № 62. Ст. 17.

2 Фіолевський Д.П. Адвокатура: підручник. 3-тє вид., випр. і доп. К.: Алерта, 2014. C. 172.

${ }^{3}$ Борзих Н.В. Адвокат як суб'єкт захисту та його повноваження. Вісник Донецького університету. Серія В «Економіка і право». 2007. № 2. С. 449. 
only regards the legal aid agreement as a document certifying the lawyer's powers but also places the utmost importance on it in the relationship between the lawyer and his/her client.

This contract is a "starting point" in the relationship between the lawyer and the principal"4, and is the basis for the realization of a person's constitutional right to professional legal assistance since its conclusion is a condition for the initiation of such assistance. The conclusion of the contract is the lawyer's responsibility, provided by the law, the violation of which may be a reason for bringing the lawyer to disciplinary liability (the decision of the Bar Council of Ukraine issued February 26, 2016 No. 74 ${ }^{5}$ ).

The Legal Aid Agreement is also the basis for the further relationship between the lawyer and the court, since in almost all procedural codes (except criminal procedural) there is a clear stipulation according to which a person whose rights, freedoms and legal interests are represented by a lawyer in court, has the right to limit the rights of the latter to commit certain procedural actions. That is, the lawyer's client determines the peculiarities of the lawyer's individual legal status, setting, in particular, the limits of his/her procedural autonomy ${ }^{6}$.

Unfortunately, there is no single point of view in legal science as to the legal nature of a legal aid agreement. This has resulted in a variety of viewpoints regarding the referring of this contract to a particular group of contracts. The Ukrainian legislator does not answer this question failing to differentiate the concepts of "legal aid" and "legal services" and being inconsistent in defining the contract name itself. Thus, in the law on the bar, he uses the name "legal aid contract", while in the CPC of Ukraine "contract with the lawyer", in other procedural codes the term "agreement on legal services" is used, in the previous version - the very term "contract” (an analogous situation has been reproduced, in particular in the Code of Administrative Offenses and Customs Code of Ukraine).

Therefore, various points of view have emerged in the legal literature regarding the definition of the legal nature of a legal aid agreement. Thus, I.I. Pankov proceeds from the existence of three main points of view regarding the legal nature of such a contract, pointing out that some authors refer the provision of legal aid to the sphere of constitutional and social relations; others consider the contract under investigation to be a special (unnamed) civil-law contract having a public-law nature; others attribute

\footnotetext{
${ }^{4}$ Коробицын М.Г. Существенные условия соглашения об оказании юридической помощи. Адвокат. 2006. № 10. С. 19.

5 Про затвердження роз'яснення щодо гарантій адвокатської діяльності та окремих умов дисциплінарної відповідальності, затверджено рішенням РАУ від 26 лютого 2016 року № 74. URL: http://unba.org.ua/assets/uploads/legislation/rishennya/ 2016-02-26-r-shennya-rau-74_56e baf5d9f 6da.pdf (дата звернення: 25.09.2019).

6 Заборовский В.В. Правовая природа независимости и самостоятельности украинского адвоката. Studia Prawnoustrojowe. 2018. № 39. S. 224.
} 
legal aid to certain types of civil liability (only to paid services, or only to a commission, or to a mixed contract) ${ }^{7}$. A common view among scholars refers a legal aid contract to a group of service contracts (O.L. Dziubenko ${ }^{8}$, M.V. Kratenko ${ }^{9}$. A number of scholars are of the opinion that the legal aid agreement is a variant of the commission (H.O. Svitlychna ${ }^{10}$, M.Yu. Yefimenko ${ }^{11}$ ). The viewpoint that the legal aid contract is regarded as a mixed agreement is also widespread (K.H. Knyhin ${ }^{12}$, D.Ye Koldayev ${ }^{13}$, Yu.V. Romanets ${ }^{14}$.

One of the most widespread viewpoints in the legal literature is the view considering a legal aid contract as an independent, specific contract, that is, a contract of a particular kind. The independent type of contract, which should be regulated in detail by the law on the bar, and not by the civil code, is indicated by I.I.Zaitseva ${ }^{15}$ and O.Ye. Shpahin ${ }^{16}$. The necessity of special civil legal regulation of the contract on rendering legal aid taking into account, first of all, its public-legal nature is also pointed out by I.I. Pankov ${ }^{17}$. All this points to the existence of different points of view regarding the legal nature of the legal aid contract, which results in the lack

${ }^{7}$ Панков И.И. Соглашение об оказании юридической помощи как особый гражданско-правовой договор. Актуальные проблемы науки ХХІ века: сб. ст. уч. науч.практ. семинара молодых ученых (г. Минск, 17 февраля 2011 г.). Минск: Минский ин-т управления, 2011. С. 44-45.

8 Дзюбенко О.Л. Загальні положення договору про надання правової допомоги (правової послуги). Вісник Луганського державного університету внутрішніх справ імені E.O. Дідоренка. 2013.Вип. 2. С. 266. URL: http://nbuv.gov.ua/UJRN/Vlduvs_2013_2_30 (дата звернення: 25.09.2019).

${ }^{9}$ Кратенко М.В Договор об оказании юридической помощи в современном гражданском законодательстве: автореф. дис. на соиск. научн. степ. канд. юрид. наук: спец. 12.00.03. Томск, 2005. С. 14.

${ }^{10}$ Світлична Г.О. Повноваження адвоката та їх посвідчення при здійсненні представництва у цивільному судочинстві. Проблеми иивільного права та процесу: матеріали наук.-практ. конф., присвяч. пам'яті проф. О.А. Пушкіна (м. Харків, 22 травня 2010 р.). Х.: Нац. ун-т внутр. справ, 2010. С. 312.

${ }_{11}$ Єфіменко М.Ю. Оформлення повноважень адвоката в цивільному процесі. Вісник Маріупольського держсавного університету. Сер.: Право. 2014. № 7. С. 185.

${ }_{12}$ Книгін К.Г. Поняття і місце договору про надання юридичних послуг адвокатом у цивільному праві України. Вісник Академії митної служби Украӥни. Сер.: Право. 2011. № 2. C. 103 .

${ }^{13}$ Колдаев Д.Е. Правовая основа взаимоотношений между адвокатом и клиентом. История, философия, экономика и право. 2013. № 1. URL: ифэп.pф/1-2013/12.pdf (дата звернення: 25.09.2019).

14 Романец Ю.В. Общая характеристика договоров оказания юридических услуг (поручение, комиссия, агентирование). Законодательство. 2001. № 4. С. 40.

15 Зайцева И.И. Адвокатура России: автореф. дис. на соиск. научн. степ. канд. юрид. наук: спец. 12.00.11. Екатеринбург, 2003. С. 33-36.

${ }^{16}$ Шпагин А.Е. Соглашение об оказании юридической помощи. Красноярск: Центр информации, 2014. С. 10.

${ }^{17}$ Панков И.И. Соглашение об оказании юридической помощи как особый гражданскоправовой договор. Актуальные проблемы науки ХХІ века: сб. ст. уч. науч.-практ. семинара молодых ученых (г. Минск, 17 февраля 2011 г.). Минск: Минский ин-т управления, 2011. C. 47. 
of a unified approach in establishing the place of such agreement among other groups of contracts. This is primarily due to the absence, as it has been already noted, of a clear distinction between the concepts of "legal aid» and "legal service» and the perception of what the subject matter of the contract is.

In one of our works, based on a comprehensive study of the concepts "legal aid" ("professional legal assistance») and "legal service», we came to the conclusion that they can be distinguished according to the subject of assistance receipt (assistance is received by a person being in a difficult (problematic) legal situation - object of assistance); the subject of assistance (a person with a special professional status - a lawyer); the mechanism of implementation and the scope of legal regulation (securing and guaranteeing the constitutional right to professional legal assistance); focus on achieving the result (a lawyer may only provide a certain outcome when providing legal aid, but in no case he/she is able to guarantee its occurrence) and the nature of the activity in which they are pursued (advocacy is an independent professional activity, which, in its nature, is not an entrepreneurial activity and devoid of commercial component $)^{18}$.

Therefore, having come to the conclusion that it is necessary to distinguish between legal aid and legal service and that legal aid should be associated with the professional activity of a lawyer, we consider it possible to assume that the legal aid contract should be regarded as an independent, specific contract, the basis of which is the law on the bar. In this case, we foremost assume that the subject matter of a contract is one of the main criteria for distinguishing one type of contract from another ${ }^{19}$, which is crucial in this delineation.

One of the most debatable issues in terms of defining the essence of the subject matter of the contract is the expediency and limits of its specification. A.H. Kucherena proceeds first of all from the viewpoint of the necessity for clear detalization of the subject matter of the contract on rendering legal aid $^{20}$. Another point of view is held by scholars ${ }^{21}$, who point out that the subject matter of a legal aid contract should not be specified in detail, given, first of all, the complexity of the maximum detalization of the legal aid volume at the time the contract was concluded.

18 Заборовський В.В. Деякі критерії розмежування понять «правова допомога» та «правова послуга» в аспекті визначення сутності професійної діяльності адвоката. Порівняльно-аналітичне право. 2016. № 5. C. 311-314. URL: http://pap.in.ua/5_2016/94.pdf;

19 Шимон С. Об'єкт і предмет договору і цивільного правовідношення: нотатки до наукової дискусії. Юридична Украӥна. 2011. № 4. С. 62.

${ }^{20}$ Кучерена А.Г. Адвокатура: ученик. 2-е изд., перераб. и доп. М.: Юристъ, 2009. С. 281.

${ }^{21}$ Ковтун Н.Н. Пределы оказания юридической помощи по соглашению. Уголовный nроиесс. 2008. № 7. С. 45.; Подольный Н.А. Всегда ли в интересах доверителя, чтобы адвокат действовал в соответствии с его волей? Адвокатская практика. 2004. № 3. С. 16. 
In our opinion, it is necessary to take into account the position according to which, first of all, one of the constituents of the subject of the contract, in addition to an indication of a legal problem (dispute) and a state body (other organization), where it is envisaged to exercise representation (protection) is also a type of legal assistance, and secondly, if the procedure for providing legal aid by a lawyer is not regulated by the procedural law, then the type of legal aid must contain a comprehensive list of specific actions to be performed by the lawyer ${ }^{22}$.

We agree with the above given view, since this approach is aimed at specifying the type of legal assistance provided by a lawyer (to prevent possible conflict situations between him/her and the client), and at the same time does not imply unreasonable restrictions on the practice of a lawyer in providing legal assistance. Therefore, the peculiarity of the subject matter of a contract for the provision of professional legal assistance (including the complexity of specifying the type of such assistance at the time of the contract conclusion), combined with the fact that such assistance is deprived of both a commercial component and the possibility of guaranteeing the occurrence of a certain result, once again confirms our view of the specific nature of the legal nature of this agreement.

The peculiarity of the contract on legal aid is manifested both at the stage of signing and terminating the contract. Thus, when signing a contract, a lawyer must undoubtedly comply with the requirements stipulated, in particular, by the Law of Ukraine "On the Bar and Practice of Law» (Article 28) and the Attorneys Code of Ethics (Section 3) ${ }^{23}$. Attention should also be paid to certain aspects of the involvement of a defense lawyer, investigator, prosecutor, investigating judge or court for the implementation of dock defence. The analysis of the provisions in Art. 49, 52, 53, 54 of the CPC of Ukraine gives the opportunity to agree with the statement that the introduction of a defense lawyer in cases according to which the law provides for his/her obligatory participation can take place without taking into account the will of the defendant (suspect) as well as concluding an agreement with him. The specifics of a legal aid agreement are also reflected in the procedure for terminating the contract. It should be noted here that, for instance, a criminal defense lawyer has the right to refuse to perform his/her duties only on the grounds provided for in Section 4 of Art. 47 of the CPC of Ukraine.

Therefore, the existence of these features, both at the stages of signing and terminating the legal aid contract, indicates the difference between this type of contract and other types of contracts (in particular, the service

22 Панков И.И. Существенные условия соглашения об оказании юридической помощи. Веснік Беларускага дзяржсаўнага эканамічнага ўніверсітэта. 2012. № 4. С. 93.

${ }^{23}$ Правила адвокатської етики, затверджені Звітно-виборним з’їздом адвокатів України від 9 червня 2017 року. URL: http://vkdka.org/wp-content/uploads/ 2017/07/PravilaAdvokatskoji Etiki2017.pdf (дата звернення: 25.09.2019). 
contracts, including the commission contract) and is an additional confirmation of our opinion on peculiarity of its nature. In addition, the provisions of Section 3 of Art. 27 in the Law of Ukraine "On the Bar and Practice of Law", according to which the contract on provision of legal services shall be subject to the general requirements of contract law which does not allow us to attribute the legal aid contract to any particular type of contract, but indicates to the need to regard it as a separate type.

Having analyzed the essence of the legal aid agreement, as well as reaching the conclusion that it is necessary to distinguish between the concepts "legal aid» and "legal service» and the possibility to agree with the statement of scholars who refer such assistance, in particular, to the sphere of constitutional legal relations, we consider it necessary to determine the scope of this contract legal regulation.

According to I.I. Pankov, the lawyer and his/her client must reach agreement on the terms of legal assistance, therefore, this agreement is a "civil-legal form of the enforcement of the right enshrined at the constitutional level and guaranteed by the state to every person» ${ }^{24}$. This necessity is due to the fact that "no sphere other than civil law is able to offer any specific means of regulating legal aid provision" ${ }^{25}$. Therefore, we share the opinion of the Ukrainian legislator, who in the above mentioned Section 3 of Art. 27 of the Law of Ukraine "On the Bar and Practice of Law" envisions that the contract on provision of legal services shall be subject to the general requirements of contract law, which in their essence are the norms of the Central Committee of Ukraine in this sphere, however, the basis for the legal regulation of the contract is the law on advocacy (in particular, the Law of Ukraine "On the Bar and Practice of Law» and the Attorneys' Code of Ethics).

Given the independent nature and specifics of the legal nature of the legal aid agreement (being the sole basis for both the exercise of advocacy and the exercise by a person of his or her constitutional right to professional legal assistance, on the one hand, it regulates the lawyer's relationship with his/her client, and on the other hand, it is the basis for further relationship of the lawyer with the court), we consider that in case neither the client nor the lawyer pursues the purpose of maintaining attorney-client privilege, which may be outlined in the terms of the agreement, it must be the main and only document certifying the attorney's powers in court.

24 Панков И.И. Соглашение об оказании юридической помощи как особый гражданско-правовой договор. Актуальные проблемы науки ХХІ века: сб. ст. уч. науч.практ. семинара молодых ученых (г. Минск, 17 февраля 2011 г.). Минск: Минский ин-т управления, 2011. С. 45.

25 Кратенко М.В Договор об оказании юридической помощи в современном гражданском законодательстве: автореф. дис. на соиск. научн. степ. канд. юрид. наук: спец. 12.00.03. Томск, 2005. С. 14. 
Therefore, we do not share the position of the Ukrainian legislator, who in the new editions of the CPC, EPC and CAP of Ukraine does not envisage the possibility of certifying the lawyer's powers through a legal aid agreement, while leaving this possibility in other legal and regulatory acts.

\section{Documents certifying the lawyer's powers (lawyer's warrant and power of attorney)}

According to Art. 26 of the Law of Ukraine "On the Bar and Practice of Law» one of the documents that certify the lawyer's powers to provide legal assistance is a lawyer's warrant. The specificity of this document is that it can certify the attorney's powers in all types of proceedings. Generally, a lawyer's warrant is considered as a written document issued by an attorney, attorney bureau or attorney company and must have a signature of the attorney. The standard form of a warrant is approved by the Provision on a Warrant for Legal (Judicial) Assistance (New Edition) ${ }^{26}$.

The lawyer's use of a warrant as a document certifying his/her powers is one of the most debatable issues in the legal literature. Proponents of the position on the expediency of the lawyer's using this document proceed from the fact that it is the most progressive and most functional lawyer's right ${ }^{27}$ or the only document that must certify his/her powers altogether ${ }^{28}$. The advantages of using a warrant, in comparison with other documents, include, first of all, the simplification of the permit to litigate the case and the possibility of its use in urgent cases, as well as maintaining the legal professional privilege (V.V. Voloshyn, O.V. Panchuk ${ }^{29}$ ). The opposite point of view is held by scholars, who point out both the illogical nature of its use $\mathrm{e}^{30}$, and the fact that no country with a developed legal tradition has a document that is analogous to a lawyer's warrant ${ }^{31}$.

${ }^{26}$ Положення про ордер на надання правничої (правової) допомоги (нова редакція), затверджено рішенням РАУ від 12 квітня 2019 року №41. URL: https://unba.org.ua/ assets/uploads/legislation/pologennya/2019-04-14-polozhennya-41_5cdc17a3782b5.pdf （дата звернення: 25.09.2019).

27 Волошин В.В. Насущні проблеми адвоката. Ордер адвоката України. Часопис Академії адвокатури України. 2011. № 4 (13). URL: http://archive.nbuv.gov.ua/ e-journals/Chaau/2011-4/11vvvoau.pdf (дата звернення: 25.09.2019).

${ }^{28}$ Борзих Н.В. Адвокат як суб'єкт захисту та його повноваження. Вісник Донецького університету. Серія В «Економіка і право». 2007. № 2. С. 448.

29 Панчук О. Окремі питання надання адвокатом правової допомоги свідку. Закон и жизнь. 2013. № 3. С. 33.

${ }^{30}$ Єфіменко М.Ю. Оформлення повноважень адвоката в цивільному процесі. Вісник Маріупольського державного університету. Сер.: Право. 2014. № 7. С. 185.; Марчук В.I. Особливості документального оформлення повноважень адвоката і вдосконалення у межах чинного законодавства. Вісн. Нац. ун-ту «Львівська політехніка». 2014. № 807. C. 178.

31 Буробин В. Адвокатский ордер - необходимость или анахронизм? URL: http://fparf.ru/news/all_news/blogs/VBurobin/ (дата звернення: 25.09.2019). 
Investigating both the historical aspect and the position of the previous legislation regarding the use of the warrant as a document certifying the lawyer's powers ${ }^{32}$, we concluded that there were significant shortcomings in its application. Thus, the need to add to the warrant and the excerpt from the contract (except for criminal proceedings), which stated the lawyer's powers as a representative (defense counsel) or the restrictions of his/her rights to execute certain procedural actions, indicated that the warrant in its essence only formally confirmed the existence of powers but did not determine the scope of these powers. All of this neutralized such unconditional advantage of the warrant as the possibility of its use in cases of providing emergency legal aid, when there is no possibility to conclude a contract for providing the assistance, taking into account the need both to submit an extract from the contract in the case of using the lawyer's warrant and to indicate the number (if available) and the date of concluding the agreement.

The adoption of Law No. 2147-VIII ${ }^{33}$ indicates that the Ukrainian legislator has changed their attitude to the use of the warrant as a document confirming the powers of the lawyer-representative. Thus, the CPC, EPC and CAP of Ukraine have already enshrined identical rules according to which the powers of a lawyer as a representative are confirmed by a power of attorney or a warrant issued under the Law of Ukraine "On the Bar and Practice of Law». Such legal regulation (the absence of the requirement to add an excerpt from the legal aid agreement to the warrant, as well as the possibility to confirm the power of the attorney-representative in such types of court, only by means of a commission in addition to the warrant), turned the warrant into one of the leading documents confirming the lawyer's powers, which can be used in all types of proceedings.

At the same time, given the provisions of Section 2 of Art. 26 of the Law of Ukraine "On the Bar and Practice of Law», which does not contain a requirement for the obligatory acceptance of a warrant by all bodies, institutions, organizations to confirm the lawyer's powers, indicates the possibility of using it, except for procedural codes, only by certain normative acts, namely: the Criminal Code of Ukraine, the Customs Code of Ukraine, however, the requirements of the need for mandatory addition of excerpt from the contract to the warrant remain unchanged, which indicates the

2 Заборовський В.В. Правова природа довіреності та ордера як документів, що посвідчують повноваження адвоката на надання правової допомоги. Реформування законодавства Украӥни та розвиток суспільних відносин в Украӥні: питання взаємодіі: матеріали Міжнародної науково-практичної конференції (м. Ужгород, 28-29 березня 2014 р.). Ужгород: Ужгородський національний університет, 2014. С. 273-276.

33 Про внесення змін до Господарського процесуального кодексу України, Цивільного процесуального кодексу України, Кодексу адміністративного судочинства України та інших законодавчих актів: Закон України від 3 жовтня 2017 року № 2147-VIII. Відомості Верховної Ради України. 2017. № 48. Ст. 436. 
inconsistency of the Ukrainian legislator on the possibility of using the document to confirm the lawyer's powers.

The existing legal regulation of the procedure for using a lawyer's warrant testifies, first, to the change by the Ukrainian legislator of their attitude to using it as a document confirming the lawyer's powers, since the warrant is in fact no longer considered as such; in fact it only formally confirmed the lawyer's powers and did not determine their scope but only served as evidence of the conclusion of a legal aid agreement between a lawyer and his/her client (given the absence of the need to file an extraction of the contract together with a warrant in most cases) and secondly, the turning of warrants into one of the leading documents.

A power of attorney is one of the documents that can attest to a lawyer's power as a representative (defense counsel) of a person in court. In accordance with the procedural codes, a power of attorney may be used by a lawyer in all types of proceedings, except in criminal proceedings (its application is allowed only by a representative of the legal entity involved in the proceedings, and only when such a representative is not a lawyer).

Exploring the ongoing debate in the civilized doctrine on the legal nature of the power of attorney ${ }^{34}$, we share the view of those scholars who broadly regard it as a unilateral juristic act ${ }^{35}$, being a complex legal structure ${ }^{36}$, the basis of which is the contract. Regarding the relationship between the power of attorney and the contract, which is the basis for its issuance, O.L. Nevzhodina views the power of attorney as "one of the most common ways of expressing the content of power from the outside, but not the basis of the powers» ${ }^{37}$. In our view, such a position is characteristic of both a lawyer acting as a representative and a representative who is not endowed with such status. However, if the contract of attorney is the basis (grounds) for the emergence of representation relations between the solicitor (representative without the status of a lawyer) and the principal, then the specifics of the legal nature of the contract on legal aid (the possibility of its certifying the lawyer's powers) indicates otherwise. All this again testifies to the special role of such an agreement and to its delimitation from the contract of commission.

34 Заборовський В.В. Довіреність як документ, що посвідчує повноваження адвоката. Порівняльно-аналітичне право. 2016. № 6. C. 270-271. URL: http://pap.in.ua/6_2016/80.pdf (дата звернення: 25.09.2019).

${ }^{35}$ Гордон А. Представительство в гражданском праве. С.-Пб.: Тип. Шредера, 1879. C. 85.; Дороженко М.Ю. Гражданско-правовое регулирование представительства: проблемы теории и законодательства: автореф. дис. на соиск. научн. степ. канд. юрид. наук: спец. 12.00.03. М., 2007. С. 18.

${ }^{36}$ Орлова М.М. Доверенность как письменное уполномочие. Бюллетень нотариальной практики. 2003. № 4. С. 22.

37 Невзгодина Е.Л. Основания добровольного представительства в современном гражданском праве России. Вестник Омского университета. 2008. № 4. С. 104.

252 
Regarding the provisions of the current editions of the CPC, ECP and CAP of Ukraine, they stipulate identical norms on the power of attorney on behalf of a legal entity (issued by signature (electronic digital signature) of an official authorized by law, constituent documents) and are almost analogous to the power of attorney on behalf of physical entities. Thus, allowing the possibility of testifying the power of attorney on behalf of physical entities, notarized or, in cases determined by law, by another person, as well as by an official of a body (institution) that has made a decision on granting a person free secondary legal aid, the CPC and the CAP of Ukraine provide for the possibility of testifying the powers by a court resolution.

With regard to the notarized powers of attorney and the powers of attorney, which are equivalent to such, the procedure for their certification is regulated, in particular, by the Law of Ukraine "On Notary» ${ }^{38}$ and the Cabinet of Ministers Resolution "On the Procedure of Certifying Covenants and Powers of Attorney Equal to Notarized Certificates» ${ }^{39}$.

Pursuant to paragraph 26 of the abovementioned Resolution, a power of attorney in the name of a lawyer should include the number and date of issuing the certificate on the right to practice as a lawyer and the organizational form of the practice of advocacy. The need to provide this additional information, on the one hand, clearly identifies the legal status of the lawyer-representative in the relevant proceedings and, on the other hands, impedes his or her ability to abuse the choice of legal status of the lawyerrepresentative or the actual representative (in particular, in terms of avoiding disciplinary liability).

Therefore, a power of attorney is one of the documents that can attest to a lawyer's powers as a representative (defense counsel) of a person in all types of judicial proceedings, except criminal proceedings. The imperfection of Ukrainian legislation on the use of a warrant and a legal aid agreement makes the power of attorney a basic document that attests to the status of a lawyer in the exercise of his/her non-procedural form of activity. However, regardless of the form in which the lawyer conducts his/her professional activity, the legal aid agreement always serves as a basis for issuing a power of attorney, which in turn is the basis for the exercise of his/her powers in the relations with other individuals.

In addition, in the aspect of examining the issue of the lawyer's powers formalization, in one of our works ${ }^{40}$ we disclose the essence of the power of

\footnotetext{
${ }^{38}$ Про нотаріат: Закон України від 2 вересня 1993 р. № 3425-XII. Відомості Верховної Ради України. 1993. № 39. Ст. 383.

39 Про порядок посвідчення заповітів і доручень, прирівнюваних до нотаріально посвідчених: Постанова Кабінету Міністрів України від 15 червня 1994 р. № 419. URL: http://zakon3.rada.gov.ua/laws/show/419-94 (дата звернення: 25.09.2019).

40 Заборовський В.В. Правовий статус адвоката в умовах становлення незалежної адвокатури України: монографія. Ужгород: Видавничий дім «Гельветика», 2017. C. 375-378.
} 
attorney, first, in the context of certifying the representative's authority in the constitutional court, and second, as one of the documents certifying the lawyer's power in providing free legal aid.

Based on the conducted research, we conclude, in particular, that a power of attorney in a constitutional court should not be considered as a document certifying the representative's powers, but as a way of delegating powers, whereas such documents may, in fact, be any documents stipulated by Art. 26 of the Law of Ukraine "On the Bar and Practice of Law». It also analyses the legal nature of an assignment by a body (agency) authorized by law to provide free legal aid, where we primarily share the existing procedure for issuing such a commission, since it aims at significantly accelerating the initiation of such assistance.

\section{CONCLUSIONS}

An important element of a lawyer's professional activity is the formalization of his or her powers, which both establishes the essence of the lawyer's relationship with his/her client and determines the peculiarities of his/her individual legal status. The lawyer's powers formalization is performed by means of documents confirming his/her powers including a legal aid agreement; a warrant (taking into account the need to submit an excerpt from such agreement in some cases); assignment by a body (agency) authorized by law to provide free legal aid and the power of attorney of a physical or legal entity.

Although a lawyer's warrant and, apart from criminal proceedings, a power of attorney are documents that certify the lawyer's powers in all types of proceedings, the sole basis for the practice of advocacy is a legal aid agreement, which in the case of neither the client nor the lawyer seeks to maintain the attorney-client privilege, which may be outlined in the terms of such agreement, should be the main and only document certifying the lawyer's powers in court.

Based on the distinction between the notions "legal aid» ("professional legal assistance») and "legal service», taking into account the peculiarities of concluding and terminating the legal aid agreement, in combination with the fact that the provision of such assistance should be associated with the lawyer's professional activity, we come to the conclusion that such agreement should be regarded as an independent, specific contract, which is a type of civil-legal contract (although unnamed in the Civil Code), and the basis of legal regulation is, in particular, the Law of Ukraine "On the Bar and Practice of Law " and the Attorneys' Code of Ethics.

The existing legal regulation of the procedure for using a lawyer's warrant testifies, first, to the change by the Ukrainian legislator of their attitude to its use as a document confirming the lawyer's powers, and, second, to turning the warrant into one of the leading documents in this aspect. A power of attorney is one of the documents that can attest to a lawyer's powers as a representative 
(defense counsel) of a person in all types of judicial proceedings, except criminal proceedings.

The imperfection of Ukrainian legislation on the use of a warrant and a legal aid agreement makes the power of attorney a basic document that attests to the status of a lawyer in the exercise of his/her non-procedural form of activity. However, regardless of the form in which the lawyer conducts his/her professional activity, the legal aid agreement always serves as a basis for issuing a power of attorney, which in turn is the basis for the exercise of his/her powers the in relations with other individuals.

\section{SUMMARY}

The article reveals the legal nature of such an important element in his/her professional activity as a lawyer's empowerment. This element not only establishes the essence of his/her relationship with a client but also determines the peculiarities of the lawyer's individual legal status being a prerequisite for the full implementation of the professional component of this status.

The article addresses the problematic issues of determining the nature of a legal aid contract, taking into account, inter alia, the lack of a unified approach to establishing the place of this contract among other groups of contracts. It also rationalizes the need to differentiate the concepts "legal aid» and "legal services», given that the provision of such assistance should be associated with the professional activity of a lawyer. Taking into account the abovementioned facts, as well as the peculiarities of both conclusion and termination of the legal aid agreement, it is concluded that it is necessary to regard the agreement as an independent, specific contract, which is a type of civil-legal contract.

This article analyzes the nature of other documents that confirm the lawyer's powers in terms of the procedural and non-procedural form of his/her activity. The advantages and disadvantages of the practical application of each of these documents are revealed, as well as attention is paid to the existing legislative gaps in their usage.

\section{REFERENCES}

1. Про адвокатуру та адвокатську діяльність: Закон України від 5 липня 2012 р. № 5076-VI. Офіційний вісник Украӥни. 2012. № 62. Ст. 17.

2. Фіолевський Д.П. Адвокатура: підручник. 3-тє вид., випр. і доп. К.: Алерта, 2014. 624 с.

3. Борзих Н.В. Адвокат як суб'єкт захисту та його повноваження. Вісник Донецького університету. Серія В «Економіка і право». 2007. № 2. C. 445-455.

4. Коробицын М.Г. Существенные условия соглашения об оказании юридической помощи. Адвокат. 2006. № 10. С. 19-22. 
5. Про затвердження роз'яснення щодо гарантій адвокатської діяльності та окремих умов дисциплінарної відповідальності, затверджено рішенням РАУ від 26 лютого 2016 року № 74. URL: http://unba.org.ua/assets/uploads/legislation/rishennya/2016-02-26-rshennya-rau-74_56e baf5d9f 6da.pdf (дата звернення: 12.08.2019).

6. Заборовский В.В. Правовая природа независимости и самостоятельности украинского адвоката. Studia Prawnoustrojowe. 2018. № 39. S. 215-229.

7. Панков И.И. Соглашение об оказании юридической помощи как особый гражданско-правовой договор. Актуальные проблемы науки XXI века: сб. ст. уч. науч.-практ. семинара молодых ученых (г. Минск, 17 февраля 2011 г.). Минск: Минский ин-т управления, 2011. С. 44-49.

8. Дзюбенко О.Л. Загальні положення договору про надання правової допомоги (правової послуги). Вісник Луганського державного університету внутрішніх справ імені Е.О. Дідоренка. 2013. Вип. 2. C. 265-275. URL: http://nbuv.gov.ua/UJRN/Vlduvs_2013_2_30 (дата звернення: 12.08.2019).

9. Кратенко М.В Договор об оказании юридической помощи в современном гражданском законодательстве: автореф. дис. на соиск. научн. степ. канд. юрид. наук: спец. 12.00.03. Томск, 2005. 30 с.

10. Світлична Г.О. Повноваження адвоката та їх посвідчення при здійсненні представництва у цивільному судочинстві. Проблеми циивільного права та процесу: матеріали наук.-практ. конф., присвяч. пам'яті проф. О.А. Пушкіна (м. Харків, 22 травня 2010 р.). Х.: Нац. ун-т внутр. справ, 2010. С. 311-314.

11. Сфіменко М.Ю. Оформлення повноважень адвоката в цивільному процесі. Вісник Маріупольського державного університету. Сер.: Право. 2014. № 7. С. 181-188.

12. Книгін К.Г. Поняття і місце договору про надання юридичних послуг адвокатом у цивільному праві України. Вісник Академії митноі служби Украӥни. Сер.: Право. 2011. № 2. С. 102-105.

13. Колдаев Д.Е. Правовая основа взаимоотношений между адвокатом и клиентом. История, философия, экономика и право. 2013. № 1. URL: ифэп.pф/1-2013/12.pdf (дата звернення: 12.08.2019).

14. Романец Ю.В. Общая характеристика договоров оказания юридических услуг (поручение, комиссия, агентирование). Законодательство. 2001. № 4. С. 38-43.

15. Зайцева И.И. Адвокатура России: автореф. дис. на соиск. научн. степ. канд. юрид. наук: спец. 12.00.11. Екатеринбург, 2003. 44 с.

16. Шпагин А.Е. Соглашение об оказании юридической помощи. Красноярск: Центр информации, 2014. 104 с.

17. Заборовський В.В. Деякі критерії розмежування понять «правова допомога» та «правова послуга» в аспекті визначення сутності 256 
професійної діяльності адвоката. Порівняльно-аналітичне право. 2016. № 5. C. 311-314. URL: http://pap.in.ua/5_2016/94.pdf (дата звернення: 12.08.2019).

18. Шимон С. Об'єкт і предмет договору і цивільного правовідношення: нотатки до наукової дискусії. Юридична Україна. 2011. № 4. C. 58-64.

19. Кучерена А.Г. Адвокатура: ученик. 2-е изд., перераб. и доп. М.: Юристь, 2009. 751 с.

20. Ковтун Н.Н. Пределы оказания юридической помощи по соглашению. Уголовный проиесс. 2008. № 7. С. 42-45.

21. Подольный Н.А. Всегда ли в интересах доверителя, чтобы адвокат действовал в соответствии с его волей? Адвокатская практика. 2004. № 3. С. 16-18.

22. Панков И.И. Существенные условия соглашения об оказании юридической помощи. Веснік Беларускага дзяржаўнага эканамічнага ўніверсітэта. 2012. № 4. С. 90-96.

23. Правила адвокатської етики, затверджені Звітно-виборним 3'їздом адвокатів України від 9 червня 2017 року. URL: http://vkdka.org/ wp-content/uploads/2017/07/PravilaAdvokatskojiEtiki2017.pdf (дата звернення: 12.08.2019).

24. Положення про ордер на надання правничої (правової) допомоги (нова редакція), затверджено рішенням РАУ від 12 квітня 2019 року № 41. URL: https://unba.org.ua/assets/uploads/legislation/pologennya/201904-14-polozhennya-41_5cdc17a3782b5.pdf (дата звернення: 12.08.2019).

25. Волошин В.В. Насущні проблеми адвоката. Ордер адвоката України. Часопис Академії адвокатури України. 2011. № 4 (13). URL: http://archive.nbuv.gov.ua/e-journals/Chaau/2011-4/11vvvoau.pdf (дата звернення: 12.08.2019).

26. Панчук О. Окремі питання надання адвокатом правової допомоги свідку. Закон и жизнь. 2013. № 3. С. 32-34.

27. Марчук В.І. Особливості документального оформлення повноважень адвоката і вдосконалення у межах чинного законодавства. $\mathrm{Bich}$. Нац. ун-ту «Львівська політехніка». 2014. № 807. С. 172-179.

28. Буробин В. Адвокатский ордер - необходимость или анахронизм? URL: http://fparf.ru/news/all_news/blogs/VBurobin/ (дата звернення: 12.08.2019).

29. Заборовський В.В. Правова природа довіреності та ордера як документів, що посвідчують повноваження адвоката на надання правової допомоги. Реформування законодавства України та розвиток суспільних відносин в Україні: питання взаємодї: матеріали Міжнародної науковопрактичної конференції (м. Ужгород, 28-29 березня 2014 р.). Ужгород: Ужгородський національний університет, 2014. С. 273-276. 
30. Про внесення змін до Господарського процесуального кодексу України, Цивільного процесуального кодексу України, Кодексу адміністративного судочинства України та інших законодавчих актів: Закон України від 3 жовтня 2017 року №2147-VIII. Відомості Верховної Ради Украӥни. 2017. № 48. Ст. 436.

31. Заборовський В.В. Довіреність як документ, що посвідчує повноваження адвоката. Порівняльно-аналітичне право. 2016. № 6. С. 270-271. URL: http://pap.in.ua/6_2016/80.pdf (дата звернення: 12.08.2019).

32. Гордон А. Представительство в гражданском праве. С.-Пб.: Тип. Шредера, 1879. 447 с.

33. Дороженко М.Ю. Гражданско-правовое регулирование представительства: проблемы теории и законодательства: автореф. дис. ... канд. юрид. наук: спец. 12.00.03. М., 2007. 26 с.

34. Орлова М.М. Доверенность как письменное уполномочие. Бюллетень нотариальной практики. 2003. № 4. С. 20-24.

35. Невзгодина Е.Л. Основания добровольного представительства в современном гражданском праве России. Вестник Омского универсиmema. 2008. № 4. C. 98-110.

36. Про нотаріат: Закон України від 2 вересня 1993 р. № 3425-XII. Відомості Верховної Ради України. 1993. № 39. Ст. 383.

37. Про порядок посвідчення заповітів і доручень, прирівнюваних до нотаріально посвідчених: Постанова Кабінету Міністрів України від 15 червня 1994 p. № 419. URL: http://zakon3.rada.gov.ua/laws/show/41994 (дата звернення: 12.08.2019).

38. Заборовський В.В. Правовий статус адвоката в умовах становлення незалежної адвокатури України: монографія. Ужгород: Видавничий дім «Гельветика», 2017. 900 с.

\section{Information about the author:} Zaborovskyy V. V.,

Doctor of Law, Associate Professor, Professor at the Civil Law And Procedure Department,

Uzhhorod National University 26, Kapitulna str., Uzhgorod, 88000, Ukraine 